副腎皮質機能の静脈麻酔時間に及ぼす影響に関する研究

\author{
第 1 編 \\ 静 脈 麻酔 の 呼吸抑制について \\ 岡山大学医学部第 1 (陣内) 外科教室（指導 : 陣内教授） \\ 川 崎 俊夫
}

〔昭和 34 年 7 月 3 日受稿]

\section{第1章 緒言ならひに文献}

Fisher and Mering3) らが Barbiturate を合成し て以来, 種なの薬剂が作られた。ながも Volwiler and Tabern3) によりペントサールが作られ静脈麻 酔が今日のように広く用いられるようになつたが， 第1の欠点は呼吸㧕制にあるととはいうまでもない. 家鬼にラボナール, チオバール, イソゾールらの静 脈麻轱をおこなつてみて，ラボナール，千オバール の呼吸抑制が目立ち，害際の称醉時間を湘定するた ふにはなはだ障碍になつた。

静脈麻酔の呼吸抑制は呼吸中枢の抑制である。乙 の場合呼吸中枢の炭酸ガスに対する感受性は低下す るかまたは消失するので3，炭酸ガスの血中及び組 織中の異常な上昇がおこつてす，呼吸中枢を刺激す るととがなししろ抑制的に働くものと考えられる. 彷つて静脈鿟酔の称酶時間を正確に測定するために は，呼吸抑制の一番少い楽剂を選ばなりればならな W.

静脈麻酔では第 3 期第 2 相までは胸式及び腹式呼 吸の両方が平行して障碍されるから1)2，乙の時期 までの呼吸抑制は胸廓運動の回数と振巾の変化をみ て知ることができる。影廟運動を電気的に導出し呼 吸州線の描記をおこない，それによつて呼吸㧕制が 暞開始後いつ頃から生じいつ頃まで著明であるか， 呼吸暴はどのくらい減少するあのであるかというこ とを予備実験として家兔及び人について研究した。

\section{第2草 実 臨方法}

\section{第 1 節 各種静脈森酔剂}

ラボナール,チオバールはともに Thiopental sod. で，製造元が違うに過ぎい．化学名は 5-ethyl5-(1-methyl butyl)-2-thiobarbiturate sod. で桡
造式む全く同じである（表 1 ).

表 1 チォペンタールソヂムムの構造式<smiles>CCCC(C)C(CC)C1NNC(SN(C)C)=NC1=O</smiles>

イソゾールは Thiamylal sod. で構造式は表 2 のでとくである.

表 2 チアミラールンチウムの構造式<smiles></smiles>

以上の 3 種の静脈剂ラボナール，チオバール， 1 ソゾールを実験に使用した。

第 2 節 呼吸曲線描記法 呼吸曲線電極はゴム管内液体（硫酸銅飽和溶液） がゴム管の伸樎にともない，その抵抗值が変化する 現象を利用して呼吸時の胸囲の変化より呼吸の深度 及び頻度を知るものである（四 1 ）。

呼気最大時に呼吸曲線電極のゴム管を少し伸ばし た状態に保つように，伸縮のない紐にて胸部に巻き つける．電源として乾電池 1 ケないし 2 ケを使用し 因1のように結線し测定する，すなわち呼気の際に は抵抗值が減少して呼吸曲線は上向きになり，吸気 では下向きになるようになつている。 
因 1 呼吸曲線配線図

\section{呼吸曲線描記法}

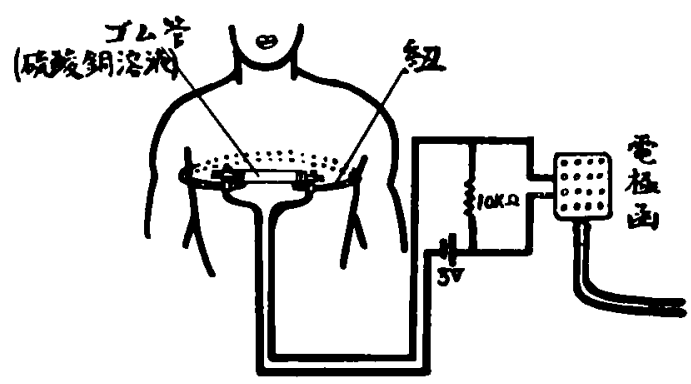

第 3 節 家鬼の静眽淋酔法及び惏醉㭙間測 定法

$2.3 \sim 2.8 \mathrm{~kg}$ の白色雄性家恖にラボナール, チ才 バール,イソゾールらの静脈晽酔剂をそれぞれ1.25 加溶液とし， $\mathrm{kg}$ 当り $1 \mathrm{cc}$ の量を 1 分間 $1 \mathrm{cc}$ の速度 で静脈注射した。各楽剂注射の間隔は 1 週間とし た7)11).

你斩㭙間測定には，注射終了時より家鬼に疼痛反 射があらわれ鼻の先においてある人参をかぎ始める までの㭙間を秝酔時間とした。

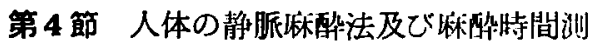
定法

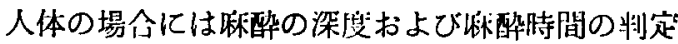
を正確にするために脳波を導出し，・同㭙に右侧第 5 肋閣筋において，同心円状釗電極で能電図の干沙波 をとり12）それらと併行して呼吸井線を記録した。 すなわちラボナール，チオバール，イソゾールらて 静脈晽轺した脳波を観察し，高振巾徐波の出ている 第 3 期第 2 相の時期を選んで呼吸抑制の程度を調へ た.

人体の埸合の静脈秝酔楽の滿成は $2.5 \%$ 溶液とし， $\mathrm{kg}$ 当り $0.5 \mathrm{cc}$ をと 1 分間 $10 \mathrm{cc}$ の速度で漷顺 注射した，注射速度が早くなると呼收㧕制が著明に あらわれるから，ての点とくに注点を払つた，注射 終了より疼痛反射出現までを愀醉㭙間とした。

\section{第3章 実 験 成 績}

\section{1) 低酔持続時間}

いま人，家鬼とむ3 種の称酔剂につきをれぞれ 5 例ずつ，計15例ずつについて测定した麻西持続時間 の平均值を示せば表 3 のごとくで，家忽，人いずれ の場合であイソゾールが一番長く，したがつて麻醉
の作用むイソゾールが最む強いととになる，すなわ ちラボナールとチオバールとではほは同一であるが， イソゾールは家鬼では約1.2倍.人では約1.3倍であ る.

表 3 家患及び人の麻酔時間

\begin{tabular}{|c|c|c|}
\hline 家兔及び人 & $\begin{array}{l}\text { 家槐麻酔㭙間 } \\
1.25 \% \text { 溶 液 }\end{array}$ & $\begin{array}{l}\text { 人の麻醉特間 } \\
2.5 \% \text { 溶 液 }\end{array}$ \\
\hline ラポナール & $10^{\prime} 20^{\prime \prime}$ & $4^{\prime} 05^{\prime \prime}$ \\
\hline チオバール & $9^{\prime} 40^{\prime \prime}$ & $4^{\prime} 18^{\prime \prime}$ \\
\hline 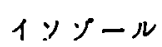 & $12^{\prime} 30^{\prime \prime}$ & $5^{\prime} 40^{\prime \prime}$ \\
\hline
\end{tabular}

2) 呼吸社減少率

正常の呼吸曲線は図2のようになり，乙の曲線と 基線とに囲まれる面皘を正常呼吸曲線面皘と呼ふ。

四 2 正常呼吸曲線面程

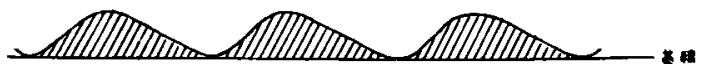

一方第 3 期筹 2 相㭙の呼吸曲線にてえた面積を抑制 呼吸曲線面皘と呼ふ，両者についてそれぞれ30秒間 にわたり各々の面皘を面䄸計にて求め, 後者の前者 に対する面皘比を計算し，この面皘比をむつて麻醉 封の呼吸毁の減少率を知るととができる。

よつて呼吸崇隇少率は次式であらわされる.

$\left(1-\frac{\text { 抑制呼吸陆線面皘 }}{\text { 正常呼吸曲線面皘 }}\right) \times 100$

いま各々 5 例ずつの家昆及び人について测定した 阿没娍少率の平均值は表 4 および表 5 のでとくな

表 4 家霓の呼吸量減少率

\begin{tabular}{|c|c|c|c|c|c|}
\hline 家 & & & & 鬼 & 呼吸量减少事(目) \\
\hline ラ & ボ & ナ & - & $n$ & $37 \not 6$ \\
\hline 于 & オ & ハi & - & $N$ & 35 \\
\hline 1 & ソ & ソ゚ & - & $N$ & 20 \\
\hline
\end{tabular}

萃 5 人の呼吸量減少率

\begin{tabular}{|c|c|c|c|c|c|}
\hline \multicolumn{5}{|c|}{ 人 } & 呼吸量減少率(96) \\
\hline $\bar{j}$ & 术 & $ナ$ & - & $M$ & $30 \%$ \\
\hline$f$ & オ & 的 & - & $ル$ & 28 \\
\hline 1 & y & $\mathscr{Y}$ & - & ル & 20 \\
\hline
\end{tabular}

る、すなわちいずれの場合すラボナールがもつとも 減少率が大で，チオボール，イソゾールの順となり， 一般に人体では家患よりあ減少率が少い。

3) 呼吸抑制の閒始及び終了時期と持続時間 呼吸㑮減少率をみたのは前述のでとく第 3 期第 2 
相時の呼吸量の変化より求めたのであるが呼吸抑制 の発生する時期は麻酔隹の種類により多少異るし, またその持続㭙間にもかなりな差異を認める.

家兔実験では，同一家兔 4 回の実験の平均を出し て表 6 に揭げた。なお呼吸抑制開始及び終了時期は， 静脈注射開始からの時間である.

表 6 家鬼の呼吸抑制開始及び䅂了 時期と持続時間

\begin{tabular}{|c|c|c|c|c|c|}
\hline \multirow{2}{*}{ 家 } & & 吸 & 抑 & 制 & \multirow{2}{*}{ 持続時間 } \\
\hline & 開 & 始 & & 了 & \\
\hline ラポナール & \multicolumn{4}{|c|}{$50^{\prime \prime} \sim 3^{\prime}$} & $2^{\prime} 10^{\prime \prime}$ \\
\hline テォパール & \multicolumn{4}{|c|}{$40^{\prime \prime} \sim 3^{\prime}$} & $2^{\prime} 20^{\prime \prime}$ \\
\hline イソソーN & \multicolumn{4}{|c|}{$1^{\prime} 20^{\prime \prime} \sim 3^{\prime}$} & $1^{\prime} 40^{\prime \prime}$ \\
\hline
\end{tabular}

呼吸抑制開姶は家鬼ではイソゾールが著しくおそ いが，人では表 7 のでとく大差がない，終了は家鬼 ではどの麻酔剂でも一定して 3 分であるが，人では イソゾールが最す早く著明な㧕制から脱している. 呼吸仿制持続時間はイソゾールがいずれの場合も最 6短い.

表 7 人の呼吸抑制開始及び終了時 期と持続時間

\begin{tabular}{|c|c|c|c|c|}
\hline \multirow{2}{*}{ 人 } & & 吸 & 抑 制 & \multirow{2}{*}{ 持続時間 } \\
\hline & 開 & 始 & 䅂了 & \\
\hline ラポナール & \multicolumn{3}{|c|}{$1^{\prime} 30^{\prime \prime} \sim 2^{\prime} 50^{\prime \prime}$} & $1^{\prime} 20^{\prime \prime}$ \\
\hline チオバール & \multirow{2}{*}{\multicolumn{3}{|c|}{$\begin{array}{l}1^{\prime} \sim 2^{\prime} \\
1^{\prime} 20^{\prime \prime} \sim 1^{\prime} 50^{\prime \prime}\end{array}$}} & $1^{\prime}$ \\
\hline 1ンソール & & & & $30^{\prime \prime}$ \\
\hline
\end{tabular}

4) 呼吸振巾之呼吸回数

人についてイソソール, チオパール, ラボナール をそれぞれ注射した前後の脳波，肋間筋筋電図，呼 吸曲線を同㭙に描記したのが図3，因4，四5であ

図3イソソール注射前後の腅波，肋間筋筋管 図および呼吸曲線

A. 注射前

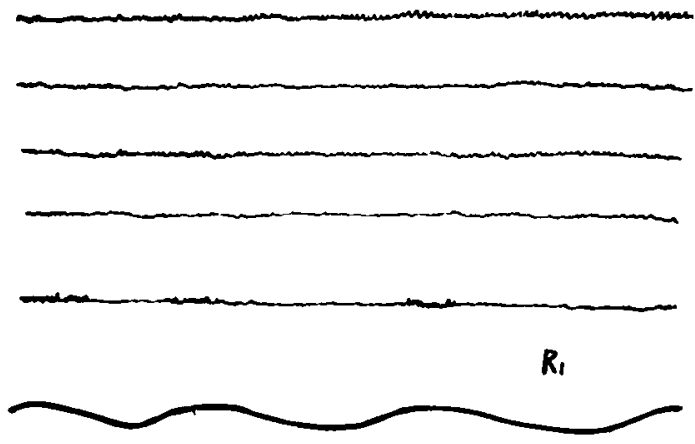

B. 注射後

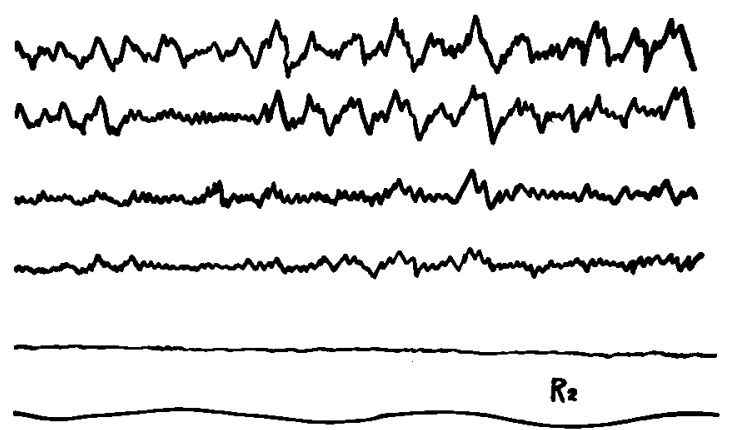

困 4 チォバール注射前後の脳波, 助間筋筋電 図括よぴ呼吸曲線

A. 注射前

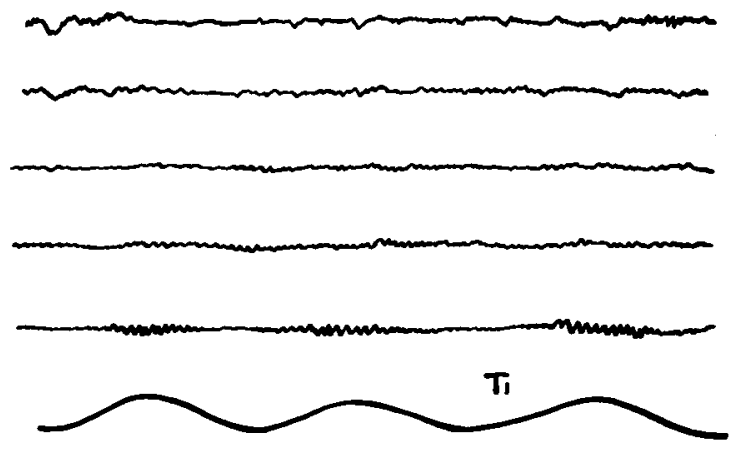

B，注射後

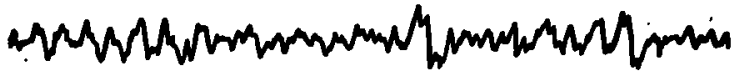

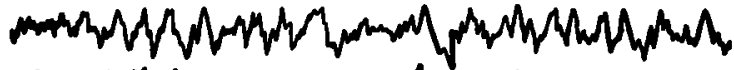

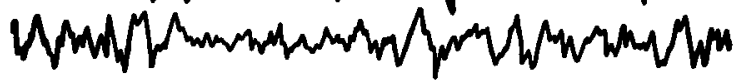

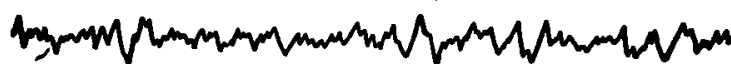

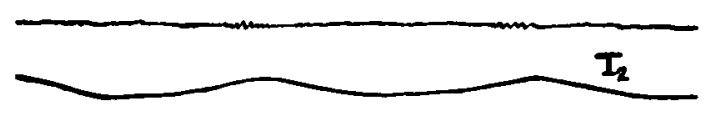

因 5 ラポナール注射前後の脳波，肋間筋筋䉓 因括よぴ呼吸曲線

A. 注射前

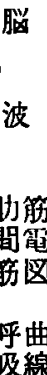


B. 注射後

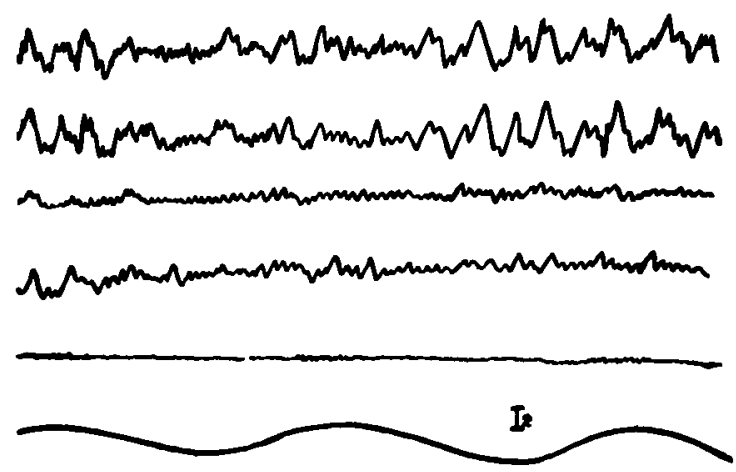

ろ. 注射後の曲線は第3期第2相となつたときのもの である. この四の曲線は上から 4 列までが脳波，次 いで助間筋筋電図，呼吸曲線の順になつている，す なわちいずれの場合す注射後は肋間筋筋電図の振巾 は注射前に比して著明に減少しているか，呼吸回数 及び振巾においてはチオペンタールソヂウムとチア ミラールソヂウムとでは，かなり違つた結果が出て いる.すなわちイソゾールでは呼吸回数はかなり減 少したが，呼吸振巾はほとんど変化がなかつた。一 方チホバール，ラボナールでは呼吸振巾に著明な減 少があつたが呼吸回数はほとんど変化がなかつた。 呼吸振巾と呼吸回数とを数で示せば表 8 のことくで ある.

表 8 人の呼吸振幅及び呼吸回数

\begin{tabular}{|c|c|c|c|c|}
\hline \multirow{2}{*}{$\lambda$} & 振 & 幅 & \multicolumn{2}{|c|}{ 回 数 (30秒) } \\
\hline & 最 小 & 最 大 & 抑 制 & 正 常 \\
\hline ラボナール & 8 & 11 & 9 & 9 \\
\hline チオパール & 7 & 10 & 9 & 9 \\
\hline イソソール & 7 & 8 & 8 & 11 \\
\hline
\end{tabular}

表 9 家鬼の呼吸振幅及び呼吸回数

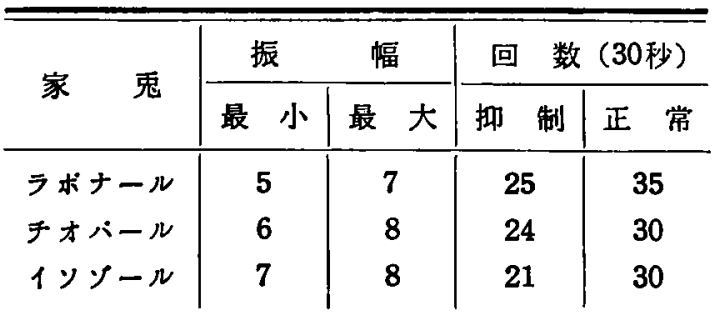

一方家鬼における実験では，チオペンタールソヂ ウムです, 人の埸合と違つて呼吸回数はかなり堿少 しているが，振巾はやはりイソゾールがもつとも変 化が少い.

\section{第4章総括ならびに考按}

チオペンタールとチアミラールとは呼吸抑制，毒 性らについて，ほとんど両者に差がないとあいわれ ているが4), Seevers らの研究では, チアミラール はチオペンタールの1.5倍強いといわれ，Relley ら の血中澋度からの比較では1.39倍强い結果になつて

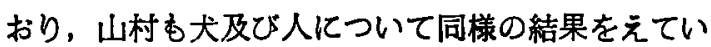
る5)。私は薬物の使用洪度を一定にし，それぞれの 麻醉時間を基準にして麻酔作用の強さをしらへてみ たが、ラボナール，チオバールではほとんど同一で あつたが，イソゾールは家兔ではそれらの約1.2倍， 人では約 1.3 倍の効力があつた。 千オペンタールも チアミラールも解毒速度の点では，ほは同一程度と みなされるから使用量が少い方が蓄皘作用は少いこ とになる，すなわちチアミラールの方がチオペンタ ールよりも強い効力をあらわすため，同一森酔深度 をうるには，少量ですみ，したがつて蕃積作用も少 いことになる。

つぎに呼吸運動に関する問題であるが，吸気は皘 極的な運動で骨格筋の収縮によつておこり，呼気は 受動的で吸気の際收樎した筋の弛䌅によつておこる あのである.そして正常時では呼気時間と吸気時間 は大体 4:3であるという.

静脈麻䣲の呼吸抑制のあらわれ方は，まず一過性 の呼吸抑制が生ずるが，第 3 期第 2 相までは胸式及 ご腹式の両方が同様に障碍される。したがつて胸部 上り導出した呼吸曲線加ら呼吸量の大小を比㬵する ことができる.

呼吸㧕制のあらわれ方には，呼吸数汃減少するむ のと振巾が隇少するすのとが考えられるが第 3 期第

2 相までの呼吸曲線を各薬剂別に追求してみると， チオペンタールの呼吸抑制は呼吸の振巾の減少の方 が著明であるのに反し，チアミラールでは，呼吸の 振巾は余り変化せず，呼吸回数が減少することを知 つた。 この事実はチアミラールでは麻醉作用が柿く， また私の実験で知りえたように呼吸抑制の開始時期 がおそくかつ呼吸抑制の持続特間がチオペンタール に比し短かいために，呼吸振巾の変化の時期が非常 に短くなり，すぐさま呼吸抑制の第 2 の段階である 呼吸数の変化に飛躍してしまうのではないかと考え られる，チオペンタールにおいても注射速度が速い とき，すなわち啝酔作用が強いときには，著明な呼 吸数堿少が直ちにあらわれてくる，てれる同し理由 によるすのであろう. 
以上のどとく，各薬剂により呼吸抑制のあらわれ 方化差があるととを知つたが，全体からみて呼吸量 の减少率は家鬼においても人においてもチオペンタ 一ルに比し，チアミラールたるインゾールがあつと あ少なく，同じくチオペンタールのうちでもラボナ ールよりチオバールの方が少ないことを呼吸曲線面 皘比から知ることができた。すすなわち，とれら静脈 麻酔剂のうちインゾールがすつとも呼吸㧕制が少く 麻䡃時間も長く，後編の副叒皮質機能の麻斩時間に 及ばす影響に関する研究に応用するのに最適である ことがかかつた。

\section{第5章 結論 \\ ラボナール，チオバール，イソゾールの 3 種の静} 脈林酔剂を用い麻䣲時間，呼吸抑制開始及び終了時 間そしてその持続時間, 呼吸韹减少率等を検討して 次の如き結論をえた。

1）僺酔持続時間はイソゾールがあつとも長く， 家鬼ではチオペンタールの約 1.2 倍, 人ではその約 1.3倍である.ラボナールとチオバールとははほとん

文

1）春山：日本外科学会雑誌，53，602

2) 策井：胸部外科，6，569，昭28.

3）古川：靜脈麻酔の㬰際，克誠堂, 1957.

4）山村他：麻醉, 金原, 1956 .

5）山村：臨床麻酼学, 医粚蒋, 1955.

6）恩地·麻酔の反省，南江堂， 1955 .

7) 細谷: 作䣲, 6, 353 356, 照32.

8）山村 日本外科全書，4，昭30.
ど等しい.

2）呼吸量減少率は，家兔，人ともにラボナール があつとも大で，ついでチオバールであり，イソゾ ールがあつとも少ない.

3）呼吸抑制の開始時期は家鬼ではイソゾールが 遅いが，人では大差がない．終了時期は家鬼では等 しいが, 人ではイソゾールがあつとも早い.

4) 呼吸抑制の持続時間は家鬼，人ともイソゾー ルがあつとも短い.

5） イソゾールでは呼吸回数はかなり減少するが 呼吸振巾ははとんど変化がない，てれに区しチオぺ ンタールでは呼吸振巾が減少し，呼吸回数は家兔で はやや減少するが，人では装化がない。

稿を終るに臨み䅂始御悡篤な御指真ならびに御校 閲を賜つた恩师陣内教授飞深甚な謝意を捧けます。

献

9）星子：新しい麻醉学入門，日本医青，1952.

10) Slocum, et al : Anesthesiology, 11, 427 434.

11）田中：岡山医学会雑誌，64，545～581. 1952.

12）卜部：日本臨休, 12,51 64, 昭29.

13）法沢：臨状外科，6，199 204, 昭26.

14）時実，他 筋電図，永井，昭29.

15) 藤田他: 生理学講䣡(上), 南山堂, 昭26.

16）和田臨床脳波，金原，昭32。 


\title{
The Influence of the Function of Adrenal Cortex upon the Duration of Intravenous Anesthesia
}

\section{Part 1. Respiratory restraint of intravenous injection.}

\author{
By \\ Toshio Kawasaki \\ 1 st. Dept. of Surgery, Okayama University Medical School \\ (Director : Prof. D. Jinnai M. D.)
}

The duration of anesthesia was estimated with three intravenous anesthetics, Ravonal, Thioval and Isozol. Using the phenomenon of the expansion and contraction of rubber tube filled with saturated blue vitriol solution which changes by respiratory movement and causes the fluctuation of resistence value of blue vitriol, the depth and frequency of respiration was estimated by pneumograph. By its curve, the beginning and end of respiratory restraint, duration of anesthesia and the decreasing ratio of respiratory volume were studied.

1) The anesthetic duraton is longest by Isozol. In rabbits it is about 1.2 times and in human about 1.3 times longer than by Thiopenthal. Ravonal and Thioval are almost the same.

2) Both in rabbits and in human, the decreasing ratio of respiration is the largest by Ravonal. Thioval follows and the smallest is by. lsozol.

3) The beginning of respiratory restraint is the latest by lsozol in rabbits but there is no significant difference in human. Its end is equal in rabbits but in human it is earliest by Isozol.

4) The duration of respiratory restraint is the shortest by Isozol both in rabbits and in human.

5) Isozol decreases the respiratory frequency markedly but scarcely changes the respiratory amplitude. On the contrary, in case of Thiopenthal, respiratory amplitude decreases and the respiratory frequency decreases slightly in rabbits but shows no variation in human. 